\title{
Androgen-modulated $p 21$ and $p 53$ gene expression in human non-transformed epithelial prostatic cells in primary cultures
}

\author{
A. POZZOBON ${ }^{1}$, L. SCHNEIDER ${ }^{2}$ and I.S. BRUM ${ }^{2}$ \\ ${ }^{1}$ Center for Health Sciences, University Center Univates, Lajeado, State of Rio Grande do Sul; ${ }^{2}$ Laboratory of Tumor and \\ Endocrine Biology, Federal University of Rio Grande do Sul, Porto Alegre, State of Rio Grande do Sul, Brazil
}

Received May 4, 2012; Accepted July 13, 2012

DOI: $10.3892 /$ ijmm.2012.1082

\begin{abstract}
The prostate gland is under androgen control. The aim of the present study was to evaluate the expression of two genes that are regulators of the cell cycle, the $p 53$ and p21 genes, in human non-transformed epithelial prostatic cells (HNTEPs) treated with different concentrations of hormones. Samples of prostate tissue were obtained from 10 patients between 60 and 77 years of age. HNTEP cells were grown in basal medium and treated with dihydrotestosterone (DHT) in different conditions for $4 \mathrm{~h}$. A low concentration of DHT resulted in a significant increase in cell growth; this effect was eradicated by addition of the antiandrogen hydroxyflutamide. Furthermore, the low concentration of DHT induced lower mRNA levels in the p53 and p21 genes in HNTEP cells. In turn, high DHT concentrations induced a significant increase in the expression of the $p 53$ and $p 21$ genes. The present data suggest that the $p 53$ and $p 21$ genes play a role in the control of responsiveness and androgen dose-dependent cell proliferation in HNTEP cells. Further studies are required to assess the intracellular signaling pathway regulated by $p 53$ and $p 21$ under the influence of androgens and its implications for the pathophysiology of prostate diseases.
\end{abstract}

\section{Introduction}

Androgens are the main regulators of prostate growth and differentiation. The proliferation mechanisms activated by androgens involve transcription factors that operate together to maintain the balance between inhibition and cell prostate proliferation (1-3). The androgen receptor (AR) is expressed in normal prostate epithelial cells, in almost all primary prostate cancer cells and in most refractory prostate cancer cells (4). Androgen concentrations and actions are determinant for prostate enlargement and are dependent on AR activity $(5,6)$. A cell line derived from a mouse xenograft

Correspondence to: Dr Adriane Pozzobon, Center for Health Sciences, University Center Univates, Rua Avelino Tallini 171, Lajeado 95900-000, State of Rio Grande do Sul, Brazil

E-mail: pozzobon@univates.br; adripozz@yahoo.com.br

Key words: androgen, $p 53, p 21$, prostate, proliferation prostate carcinoma (PCa), CWR22R3, maintains a high level of AR expression. These cells were infected with retroviruses encoding AR-specific short hairpin RNA (shRNA), and AR downregulation was demonstrated by anti-AR immunoblotting; also, the cells expressing AR shRNA showed reduced cell density (6). Finally, blocking AR activity is a therapeutic approach for benign prostate hyperplasia (BPH) and $\mathrm{PCa}(7,8)$.

While the stimulatory effect of androgens on in vivo growth and development is well recognized in several animal models and in human prostate, the in vitro characterization of these effects is a complex issue. There have been reports on the effects of androgens on the growth of normal epithelial prostate cells (9), on stromal cells of BPH tissue (3) and on AR expression $(7,8,10,11)$. By contrast, other studies were not able to show any effect of androgens, at different concentrations, on the cell proliferation of normal, hyperplasic or tumoral prostate cells (12-14). The fact that such studies were carried out on immortalized or transformed cells might be related to the variation in the results.

Studies using the LNCaP and MOP androgen-dependent prostate epithelial cancer cell lines have demonstrated a biphasic effect of androgens on proliferation, in which lower androgen concentrations have a maximum effect on cell proliferation (1,15-17). In addition, androgen shutoff genes (AS1, AS2 and AS3) have been demonstrated in LNCaP cells, and their gene expression was reported to be induced by higher concentrations of DHT $\left(10^{-9} \mathrm{M}\right)$ in the culture medium (18). We have also recently shown a stimulatory effect of androgens at low concentrations on cell proliferation of human non-transformed epithelial prostatic cells (HNTEP cells). This effect was eradicated by the addition of hydroxyflutamide (OH-Flutamide), an AR inhibitor (19). Moreover, this biphasic effect on HNTEP cell proliferation was associated with changes in mRNA levels of $c$-myc (19), $c$-fos and $c$-jun (20).

Molecular mechanisms regulating the cell cycle are key processes in the proliferation and differentiation of a target tissue. These include both apoptosis and cell progression through the cell cycle. Apoptosis is a genetically regulated process, which requires the expression and action of gene products and coregulators in order to occur (21). Progression through the G1-phase cell cycle is associated with cyclins and cyclin-dependent kinase (CDK) complexes. This effect depends on several factors including the levels of CDK inhibitors (CDKIs) (22). The $p 21$ gene is a CDKI member of the CIP/KIP 
family that includes $p 27$ and $p 57 . p 21$ prevents DNA synthesis and leads to growth arrest $(23,24)$. The expression of the $p 21$ gene in prostate cells can be activated through growth factors (25), androgens $(26,27)$ and $p 53$, a suppressor gene (28).

$p 53$ is a tumor-suppressor gene that regulates the expression of genes involved in cell cycle inhibition, apoptosis and genomic stability. The $p 53$ gene is the most commonly mutated or deleted gene in human cancer (28). Higher levels of mutated $p 53$ were found in prostate intraepithelial neoplasia (PIN), further implicating $p 53$ mutation or loss as an early event in prostate tumorigenesis (29). A recent study showed a decrease in $p 53$ mRNA levels after $8 \mathrm{~h}$ of treatment with dihydrotestosterone in a prostate cell line (LNCaP) compared with an untreated group. They also found 4 potential AREs in the $p 53$ gene: 1 in the $5^{\prime}$ flanking region, 1 in the first exon and 2 sites in the first intron (30).

Although $p 21$ and p53 appear to be associated with abnormal growth of prostate epithelial cells under the influence of androgens $(26,27,30,31)$, their involvement in the biphasic effect of androgens on prostate cell proliferation has yet to be clearly defined. Therefore, the aim of the present study was to determine the effect of androgen at different concentrations on $p 21$ and $p 53$ gene expression in HNTEP cells.

\section{Materials and methods}

Cell culture. Samples of prostate tissue were obtained from retropubic prostatectomies of 10 patients between 60 and 77 years of age, diagnosed with BPH. Patients with malignant tumors were excluded. The local Ethics Committee approved the study protocol. Informed consent was obtained from all subjects.

HNTEP cells were cultured as previously described (32). Briefly, after removal of blood clots, prostate tissue was washed with Hank's balanced salt solution (HBSS; Gibco-BRL, Grand Island, NY, USA) plus kanamycin $(0.5 \mathrm{mg} / \mathrm{ml})$ (Sigma Chemical Co., St. Louis, MO, USA), and then finely minced into $2-3 \mathrm{~mm}$ pieces. Tissue fragments were treated with collagenase type IA ( $7.5 \mathrm{mg} / \mathrm{g}$ of tissue) (Sigma Chemical Co.) in HBSS. Enzymatic digestion proceeded for $3 \mathrm{~h}$ at $37^{\circ} \mathrm{C}$ with gentle shaking. The enzymatic reaction was interrupted by the addition of warm 199 culture medium (Gibco-BRL) plus kanamycin and 10\% fetal bovine serum (FBS) (Gibco-BRL).

Epithelial cells were separated by differential filtration. Cell suspensions were distributed into $35-\mathrm{mm}$ tissue-culture dishes (Corning Glassworks, NY, USA), $1 \times 10^{5}$ cells/dish, or into 24-well tissue-culture plates (NUNC ${ }^{\mathrm{TM}}$, Denmark), $2 \times 10^{4} \mathrm{cells} / \mathrm{ml} / \mathrm{plate}$, and maintained at $37^{\circ} \mathrm{C}$ in a humidified atmosphere of $95 \%$ air $/ 5 \% \mathrm{CO}_{2}$ (NuAire, Inc., Plymouth, $\mathrm{MN}$, USA). In addition, since it is difficult to observe the stimulatory effect of androgen on cell growth in vitro, a culture medium that was free of growth factors (such as insulin or EGF) other than those present in FBS was used. The basal medium consisted of medium 199 containing kanamycin $(0.5 \mathrm{mg} / \mathrm{ml})$ enriched with 5\% charcoal-stripped FBS (cFBS). Cultures were kept in the same medium for the first 2 days, and then the medium was changed every 2 days.

Cell proliferation. MTT colorimetric assay was used to study cell proliferation. The MTT assay is based on the reduction of 3-(4,5-dimethylthiazol-2-yl)-2,5-diphenyltetrazolium bromide (MTT; Sigma Chemical Co.) to a blue formazan product by mitochondrial dehydrogenase found in viable cells (33). Epithelial cells $\left(2 \times 10^{4}\right.$ cells $\left./ \mathrm{ml}\right)$ were allowed to adhere overnight in 24-well tissue-culture plates in basal medium. On the following day, designated Day 0 , the basal medium was removed and the experimental medium was applied. The experimental medium consisted of basal medium and treatments with DHT $\left(10^{-8}, 10^{-10}\right.$ and $\left.10^{-13} \mathrm{M}\right)$ alone or combined with hydroxyflutamide (OH-FLU) at $10^{-6} \mathrm{M}$ or ethanol vehicle (control medium). Cells were cultured under routine conditions, and the medium was changed on Day 2. On Day 6, $50 \mu 1$ of $5 \mathrm{mg} / \mathrm{ml}$ MTT in PBS was added to each well. After $4 \mathrm{~h}$ of incubation at $37^{\circ} \mathrm{C}$, the medium was removed, $100 \mu \mathrm{l}$ of DMSO was added, and optical density was measured at $540 \mathrm{~nm}$ in an ELISA reader (Benchmark Microplate Reader). The data represent the mean of 3-6 wells of each treatment. Experiments were repeated at least three times, using samples from different patients.

Extraction of RNA and synthesis of cDNA. Cells were grown in basal medium deprived of serum for $4 \mathrm{~h}$, and then treated with DHT or ethanol vehicle in different conditions for $4 \mathrm{~h}$. Subsequently, the mRNA was extracted. The extraction of RNA and the synthesis of cDNA were carried out as previously described (19). Prostatic cells in culture were washed twice with PBS and homogenized in phenol-guanidine isothiocyanate (TRIzol; Invitrogen, Carlsbad, CA, USA). Total-RNA was extracted with chloroform and precipitated with isopropanol by $12,000 \mathrm{x}$ g centrifugation at $4^{\circ} \mathrm{C}$. The RNA pellet was washed twice with $75 \%$ ethanol, resuspended in diethylpyrocarbonate-treated water, and quantified by light absorbance at $260 \mathrm{~nm}$. First-strand cDNA was synthesized from $1 \mu \mathrm{g}$ total-RNA, using the SuperScript Preamplification System (Invitrogen). After denaturing the template RNA and primers at $65^{\circ} \mathrm{C}$ for $5 \mathrm{~min}$, reverse transcriptase was added in the presence of $20 \mathrm{mM}$ Tris- $\mathrm{HCl}(\mathrm{pH} 8.4)$ plus $50 \mathrm{mM} \mathrm{KCl}$, $2.5 \mathrm{mM} \mathrm{MgCl}_{2}, 0.5 \mathrm{mM}$ dNTP mix and $10 \mathrm{mM}$ dithiothreitol, and incubated at $42^{\circ} \mathrm{C}$ for $50 \mathrm{~min}$. The mixture was heated at $70^{\circ} \mathrm{C}$ to interrupt the reaction, and then incubated with $E$. coli RNase for $20 \mathrm{~min}$ at $37^{\circ} \mathrm{C}$ to destroy the untranscribed RNA.

Real-time PCR conditions. Amplification and detection were performed with the MiniOpticon Real-Time PCR detection system (Bio-Rad Life Science Research, Hercules, CA, USA). Duplicate samples were used. The PCR mixture contained $1.25 \mu \mathrm{l}$ SYBR-Green, $2 \mathrm{ng}$ cDNA at 1:50 dilution, $3 \mathrm{mM}$ $\mathrm{MgCl}_{2}, 20 \mathrm{mM}$ Tris- $\mathrm{HCl} \mathrm{pH} 8.4$ plus $50 \mathrm{mM} \mathrm{KCl}, 0.2 \mathrm{mM}$ dNTP mix, 1 unit TaqDNA polymerase and $0.4 \mu \mathrm{M}$ of each primer in a $25-\mu \mathrm{l}$ final volume. The reaction conditions were $94^{\circ} \mathrm{C}$ for $2 \mathrm{~min}$ for hot-start, and 39 cycles of $94^{\circ} \mathrm{C}$ for $50 \mathrm{sec}$, $59^{\circ} \mathrm{C}$ for $30 \mathrm{sec}$ and $72^{\circ} \mathrm{C}$ for $40 \mathrm{sec}$ for the p53 gene; and $94^{\circ} \mathrm{C}$ for $50 \mathrm{sec}, 57^{\circ} \mathrm{C}$ for $30 \mathrm{sec}$ and $72^{\circ} \mathrm{C}$ for $40 \mathrm{sec}$ for the $p 21$ gene. The sequences of primers employed were: $p 53$ gene, sense, 5'-CTGAGGTTGGCTCTGACTGTACCA-3' and antisense, 5'-CTCATTCAGCTCTCGGAACATCTC-3' (http://frodo. wi.mit.edu/cgi-bin/primer3/primer3_www.cgi); $p 21$ gene, sense, 5'CTCAG7AGGAGGCGCCATG 3' and antisense, 5'-GGGCGGATTAGGGCTTCC-3' (25). For normalization of the expression levels, the expression of $\beta 2$-microglobulin 
A

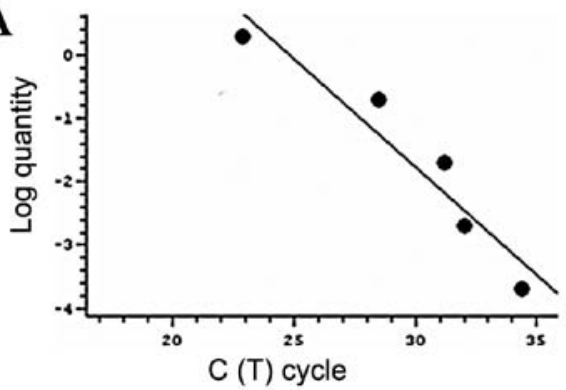

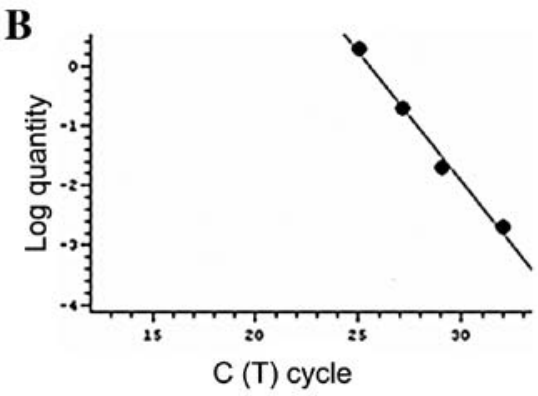

Figure 1. Standard curves of real-time PCR for the (A) p53 and (B) p21 genes performed on a dilution series of cDNA standard. Real-time PCR assay was analyzed in the linear phase and a fit linear function of the $\log$ of relative fluorescence vs. cycle number with a typical $\mathrm{R}^{2}$ value $>0.9$.

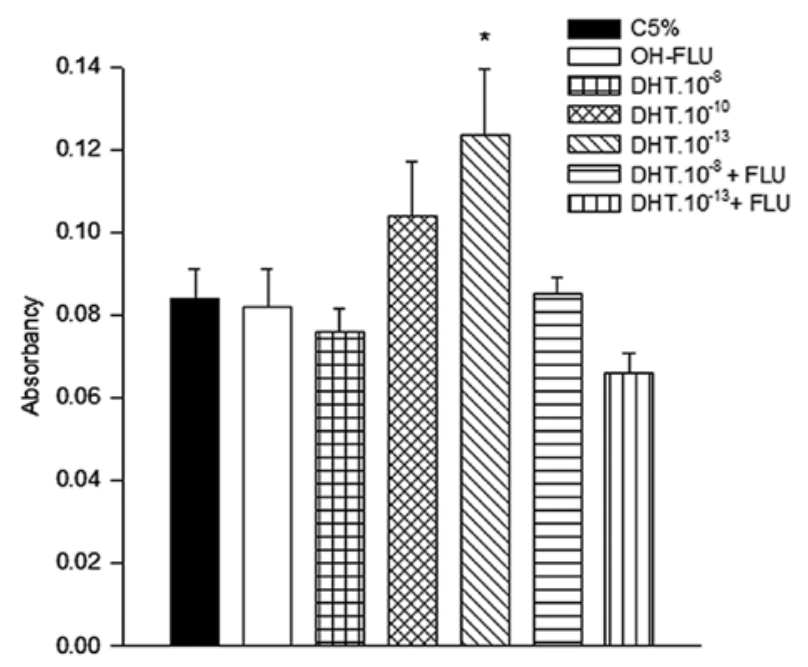

Figure 2. Effect of dihydrotestosterone (DHT) on primary culture of HNTEP cells. Cells were grown in medium 199 with 5\% charcoal-striped fetal bovine serum supplemented with or without antiandrogen hydroxyflutamide (OH-FLU) or with DHT.10-13, $10^{-10}$ or $10^{-8} \mathrm{M}$ alone or with OH-FLU. Cell proliferation was studied by MTT colorimetric assay on Day 6. Each bar represents the mean \pm SEM of 6 separate experiments performed in 9-19 wells each. For statistical analysis, ANOVA followed by Duncan's test was used ${ }^{*} \mathrm{P}<0.05$ vs. control group (C), OH-FLU, $10^{-8}$ and DHT.10 ${ }^{-13}+$ FLU.

(sense, 5'-ATCCAGCGTACTCCAAAGATTCAG-3' and antisense, 5'-AAATTGAAAGTTAACTTATGCACGC-3' (34) was used as a housekeeping gene.

Standard curves and efficiency. All samples were automatically processed for melting-curve analysis of amplified cDNA. The melting temperature $\left(\mathrm{T}_{\mathrm{m}}\right)$ is specific to each amplicon. The melting temperature for $p 53$ was $89^{\circ} \mathrm{C}$, for $p 2193^{\circ} \mathrm{C}$ and for $\beta 2$-microglobulin $83^{\circ} \mathrm{C}$. Standard curves were constructed by plotting the $\mathrm{C}_{\mathrm{T}}$ (cycle threshold) values of the real-time PCR performed on a dilution series of CDNA standard. The realtime PCR assay was analyzed in the linear phase, and a linear function was fitted of the log of relative fluorescence vs. cycle number with a typical $\mathrm{R}^{2}$ value $>0.9$ (Fig. 1). The results of the gene expression corrected by the housekeeping gene were expressed as the proportional change (1-, 2- or 3-fold) in relation to the control group.

Western blotting. Protein samples of HNTEP cells in culture were obtained with TRIzol reagent (Invitrogen) following the manufacturer's protocol. The protein concentration was determined by the Bradford method (35). Sodium dodecyl sulfate (SDS) polyacrylamide gel electrophoresis was carried out using a miniprotein system (Bio-Rad Life Science Research) with broad-range molecular weight standards. Total protein of $6.5 \mu \mathrm{g}$ was loaded onto each lane with a loading buffer containing $0.375 \mathrm{M}$ Tris (pH 6.8), 50\% glycerol, 12\% SDS, $0.5 \mathrm{M}$ dithiothreitol and $0.002 \%$ bromophenol blue. Samples were heated at $100^{\circ} \mathrm{C}$ for 3 min prior to gel loading. Following electrophoresis, proteins were transferred to nitrocellulose membranes (Schleicher and Schuell) using an electrophoresis transfer system (mini Trans-Blot Electrophoretic Transfer Cell) at $110 \mathrm{~V}$ for $1-2 \mathrm{~h}$. The membranes were then washed with TTBS (20 mM Tris- $\mathrm{HCl}, \mathrm{pH} 7.5 ; 150 \mathrm{mM} \mathrm{NaCl} ; 0.05 \%$ Tween-20, pH 7.4) and $8 \%$ non-fat dry milk for $90 \mathrm{~min}$. The membranes were incubated overnight at $4{ }^{\circ} \mathrm{C}$ with the primary antibody (monoclonal anti-p21 antibody and monoclonal antip53) (Upstate Biotechnology) diluted in TTBS. After washing, the membranes were incubated for $2 \mathrm{~h}$ at room temperature with secondary antibody (rabbit anti-mouse IgG conjugate 1:3,000 (Bio-Rad Life Science Research), washed with TBS (20 mM Tris- $\mathrm{HCl} ; 150 \mathrm{mM} \mathrm{NaCl}$, pH 7.5), and developed with the chemoluminescence ECL Western Blotting system (Amersham) followed by apposition of the membranes to autoradiographic film (Kodak X-Omat). The optical density (OD) of the bands was analyzed using an image-processing system (Image Master VDS; Pharmacia Biotech, Uppsala, Sweden). Ponceau $\mathrm{S}$ staining was used as a protein loading control for p21 and $\beta$-tubulin $(1: 10,000)$ for p53.

Statistical analysis. Data are reported as means and standard error of the mean (SEM). Differences between groups were assessed by analysis of variance, followed by Duncan's test. All analyses were performed using the Statistical Package for Social Sciences (SPSS, Chicago, IL, USA). Data were considered to indicate statistically significant differences at $\mathrm{P}<0.05$.

\section{Results}

The effect of DHT on the growth of HNTEP cells was examined on Day 6 of culture. Data were compared to those of cells treated with control medium. Cells treated with DHT at a concentration of $10^{-13} \mathrm{M}$ showed a higher proliferation rate $(\mathrm{P}<0.05)$ compared to cells from the other groups: DHT.10 ${ }^{-8} \mathrm{M}$, control medium, OH-FLU or DHT. $10^{-13} \mathrm{M}$ combined with OH-FLU (Fig. 2). 


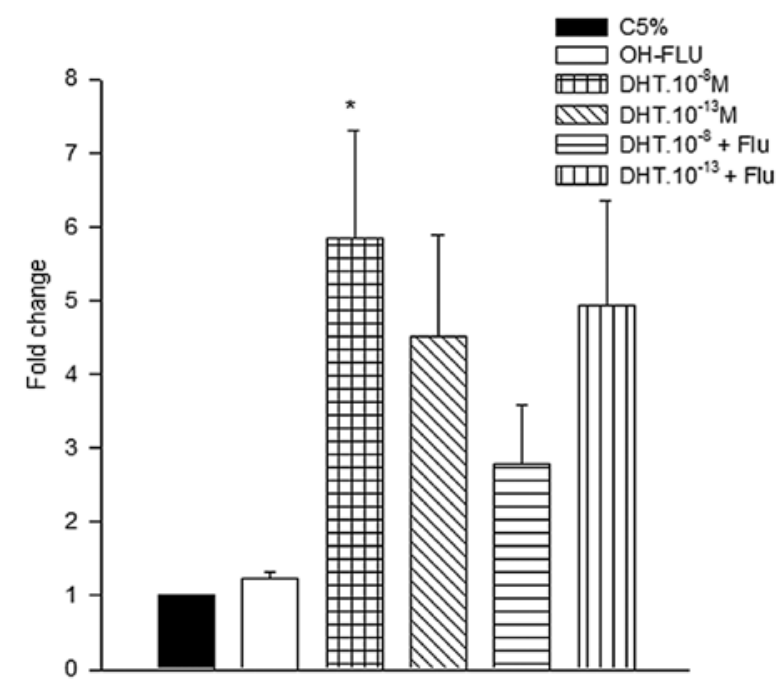

Figure 3. 53 mRNA quantitative results by real-time PCR. The graphic represents the fluorescence change in the relative expression of $p 53$ in HNTEP cells treated with hydroxiflutamide (OH-FLU) at $10^{-6} \mathrm{M}$ or dihidrotestosterone at $10^{-8}$ and $10^{-13} \mathrm{M}$ isolated or combined with OH-FLU. Comparisons between groups were analyzed by ANOVA followed by Duncan's test. ${ }^{*} \mathrm{P}<0.05$ vs. control group, OH-FLU.10-6 ${ }^{-6}$ DHT. $10^{-13}$ and DHT. $10^{-8}+$ OH-FLU.

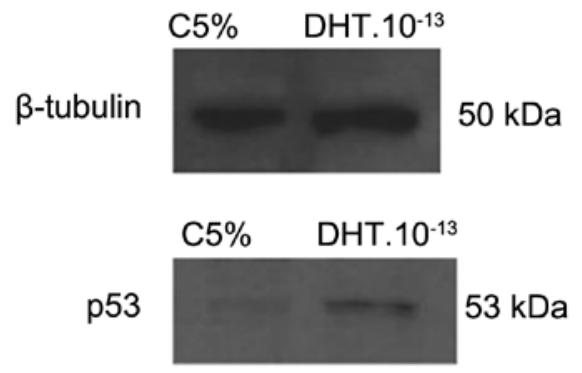

Figure 4. Autoradiogram of p53 protein levels of HNTEP cells treated with DHT. $10^{-13} \mathrm{M}$ for $4 \mathrm{~h}$. Samples were separated in a $12 \%$ SDS-PAGE, transferred to a nitrocellulose membrane and incubated with anti-AR antibody. $\beta$-tubulin staining was used as protein loading control.

A quantitative analysis of mRNA levels of the $p 53$ and $p 21$ genes in HNTEP cells was performed after $4 \mathrm{~h}$ with different treatment conditions.

The effect of DHT treatment on $p 53$ and $p 21$ mRNA levels in HNTEP cells was estimated by quantitative analysis. The p53 mRNA levels were 6-fold higher in HNTEP cells treated with DHT. $10^{-8} \mathrm{M}$ compared to the control group. The $p 53$ mRNA level of this group was also higher compared with the OH-FLU.10-6 ${ }^{-6}$ DHT. $10^{-13}$ and DHT.10-8 + OH-FLU groups (Fig. 3). To confirm the presence of $p 53$ in HNTEP cells, we evaluated the protein levels of p53 treated for $4 \mathrm{~h}$ with DHT at $10^{-13} \mathrm{M}$. Western blot analysis showed an immunoreactivity of p53 corresponding to a $53 \mathrm{kDa}$ protein in HNTEP cells (Fig. 4).

The data presented in Fig. 5 show that HNTEP cells treated with DHT.10-8 M expressed 4-fold higher $p 21$ mRNA levels than the control group. This level of expression was also significantly higher compared with the other groups. The protein level of $p 21(21 \mathrm{kDa})$ was analyzed after $4 \mathrm{~h}$ with androgen treatment. The data shown in Fig. 6 suggest an increase in the protein level of $p 21$ in the group treated with DHT. $10^{-8} \mathrm{M}$ compared to the other groups.

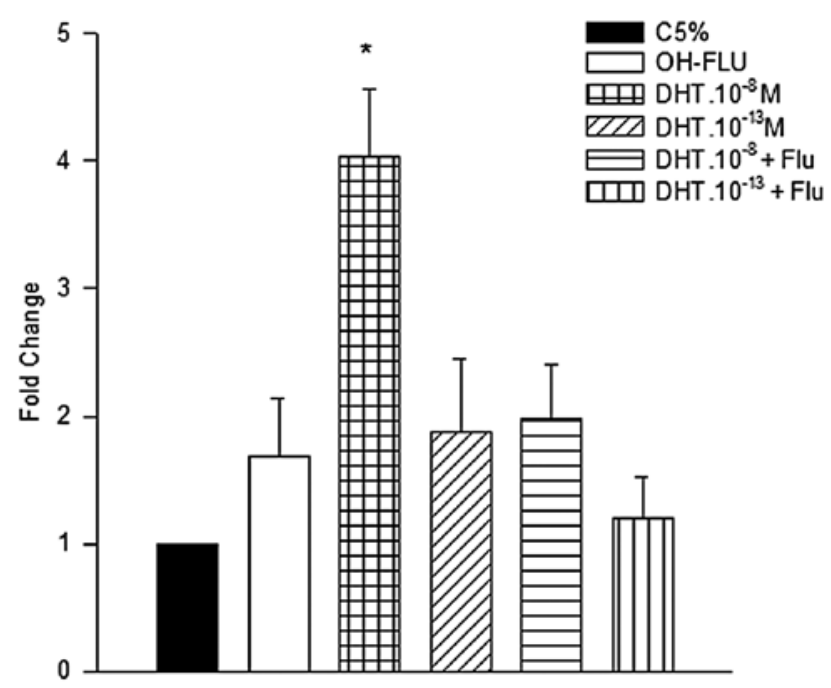

Figure 5.p21 mRNA quantitative results by real-time PCR. The graphic represents the fluorescence change in relative expression of $p 21$ in HNTEP cells treated with hydroxiflutamide (OH-FLU) at $10^{-6} \mathrm{M}$ or dihidrotestosterone at $10^{-8}$ and $10^{-13} \mathrm{M}$ isolated or combined with OH-FLU. Comparisons between means for different groups were analyzed by ANOVA followed by Duncan's test. ${ }^{*} \mathrm{P}<0.05$ vs. the others groups.

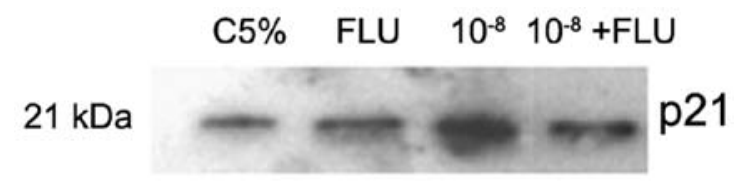

Figure 6. Representative western blot analyses of the $p 21$ gene in HNTEP cells with different treatments for $4 \mathrm{~h}$. Ponceau $\mathrm{S}$ staining was used as protein loading control.

\section{Discussion}

The results of the present study showed that low concentrations of androgens exerted a positive effect on cell proliferation in HNTEP cells, and high concentrations maintained proliferation similar to that of the control. There are several experimental models for the study of prostate growth $(1,7,12,36)$ and each of these models responds differently to stimulation. Therefore, these models may not be appropriate for investigating the effects of androgens on growth and differentiation of prostate epithelial cells. The epithelial prostate cells (HNTEP) were established as an in vitro model to study the androgen dependence of human prostate, and have previously been characterized both functionally and morphologically (32).

In our study, the effect of the low concentration of androgen was blocked by adding the anti-androgen OH-FLU to the culture medium. In a parallel study, we assessed the AR gene expression in HNTEP cells using the same mRNA employed for the $p 21$ and $p 53$ analysis in these data. In this case, the AR gene expression did not change with different treatments of DHT (data not shown). These data confirmed our previous studies on cell proliferation (19) and supported the theory that the mitogenic effect of the low dose of DHT in HNTEP cells is regulated by its own receptor, the AR. There are few studies regarding the effects of androgens in non-transformed cell models. A study by Shao et al (17) confirmed a biphasic effect 
of androgens on prostate cancer cells using the prostate cancer cell line LNCaP. They showed that a concentration higher than $1 \mathrm{nM}$ of a synthetic androgen, R1881, inhibited cell growth, whereas concentrations of $0.1 \mathrm{nM}$ and below stimulated proliferation. This biphasic effect of androgens on cancer cells was previously demonstrated by other groups $(1,15,16)$, but the effect of androgen on the growth of the non-transformed cells remains uncertain. The actions of androgen are controversial and complex, since after binding to androgen, AR is able to recruit general transcription factors to its target gene promoters. It has become clear that the transcriptional activity of AR is regulated by coregulators, including both coactivators and corepressors, by various mechanisms (37).

The present study also showed that the expression of the $p 53$ and $p 21$ genes differs according to the androgen concentrations added to the culture medium of HNTEP cells. Thus, cells incubated at low DHT concentrations exhibited lower $p 53$ and $p 21$ mRNA levels than those treated with DHT at $10^{-8} \mathrm{M}$. The inhibition of these tumor suppressor genes suggested that under the influence of low concentrations of androgens, HNTEP cells are induced to progress into the cell cycle.

Androgens can stimulate proliferation and differentiation and suppress apoptosis in the prostate gland (21). Defects in apoptotic signaling pathways are common in cancer cells. Inhibition of apoptosis is important for tumor initiation, since apoptosis is involved in the process of eliminating cells with different anomalies that lead to malignant transformation. There are many apoptosis-modulating proteins, such as Akt and $p 53(38,39)$. Mutations of the $p 53$ gene are associated with tumors and proliferative disturbance of prostate tissue (29). In this study, we worked with the wild-type form of $p 53$, demonstrating an increase of $p 53 \mathrm{mRNA}$ levels with the higher dose of DHT after $4 \mathrm{~h}$ of treatment. We showed that the anti-androgen hydroxyflutamide blocked this effect, indicating that the p53 gene is a target of androgen modulation in HNTEP cells. In the present study we also assessed the protein expression of p53 in HNTEP cells to determine the presence of functional protein. The results regarding protein levels of p53 are controversial. Bruckheimer et al (40), reported an increase in the protein levels of p53 and Bax after treatment with $1 \mathrm{nM}$ of DHT in a hormone-sensitive LNCaP-FGC cell line. Moreover, some studies have shown a decrease in protein levels of the p53 gene in LNCaP after $24 \mathrm{~h}$ of treatment with DHT over a range of $10^{-11}$ to $10^{-7} \mathrm{M}(41)$. These results could be due to post-transcriptional adjustments which result in p53 stabilization. Rokhlin et al (30), using the same cell line (LNCaP), also reported a decrease in the levels of $p 53$ mRNA after 3 days of treatment with $10^{-11}$ and $10^{-9} \mathrm{M}$ of DHT, and an important role in TNF- $\alpha$ mediated apoptosis in LNCaP cells (39). There are androgen-responsive elements in the $p 53$ gene, which may explain the regulation of this gene expression by androgens (30). There is little information on androgen modulation of $p 53$ expression in non-transformed epithelial prostate cells. Khan et al (42) reported a higher expression of the $p 53$ gene in the prostate gland of E6-AP (E6-associated protein)-null mice, suggesting that E6-AP deletion attenuates the growth and development of the prostate gland by interfering with AR function as well as by stimulating $p 53$-mediated apoptosis.

Previous studies have reported p53 expression in prostate tumors and immortalized cell lines $(43,44)$. The p53 gene may influence the expression of other genes; the present study analyzed the expression of the $p 21$ gene, which has been reported to be a target of $p 53$ action $(23,28,42,45)$.

The $p 21$ gene induces apoptosis mechanisms and blocks the progression into the cell cycle $(24,45)$. Although the role of the 21 gene in prostate diseases is not well established, the existence of an androgen-responsive element in its promotor region suggests that this gene may be modulated by the androgen receptor (46). Evidence from the LNCaP and HPr-1 cell lines suggests that $p 21$ is involved in the mechanism of androgen action at different doses $(26,27,31,47)$. Our results showed a decrease in $p 21$ gene expression in HNTEP cells treated with low androgen concentrations, and an increase at high doses. These data are consistent with the results of others who reported an increase in $p 21 \mathrm{mRNA}$ levels in $\mathrm{LNCaP}$ treated with a high dose $\left(10^{-8} \mathrm{M}\right)$ of synthetic androgen (48). Moreover, a human cell line PC-3 transfected with AR, when treated with $10 \mathrm{nM}$ of DHT, showed upregulation of $p 21$ levels, and the knockdown of AR expression also resulted in downregulation of $p 21$ protein levels (49). A recent study by semiquantitative RT-PCR analysis showed a high expression of the $p 21$ gene in DU145-Id4 cells, a lineage of DU145 cells transfected with Id4 (inhibitor of differentiation 4, a member of the Id gene family) and PrEC cells (an immortalized lineage of normal human prostatic epithelial cells) as compared to parental DU145 cells. In this study a highly significant increase (over 15 -fold by real-time PCR) in p53 gene expression was found in the DU145-Id4 cell line compared to DU145 cells (50). To the best of our knowledge, this is the first report demonstrating the regulation of suppressor genes $p 53$ and $p 21$ by androgen in human non-transformed epithelial prostatic cells in primary culture (HNTEP).

We also analyzed the protein levels of $p 21$. Protein expression tended to increase when HNTEP cells were treated with high concentrations of DHT $\left(10^{-8} \mathrm{M}\right)$. The increase in the $p 21$ protein levels by high doses of androgens has been demonstrated in other cell-culture models using different prostate-cell lines $(26,27,48)$. The results of the proliferation rates of the HNTEP cells submitted to androgen treatment could be interpreted as indirect evidence favoring the hypothesis of involvement of these genes in the regulation of the cell cycle, associated with different doses of androgens. Taken together, these data may indicate that under the influence of androgens the expression of both $p 53$ and $p 21$ genes could be differentially changed in order to allow modulation in cell proliferation.

Benign prostatic hyperplasia (BPH) is the most prevalent disease of the prostate. The incidence of $\mathrm{BPH}$ coincides with decreasing circulating testosterone levels in senescence (51) and is associated with an imbalance between the rate of cell proliferation and cell death. The association between low concentrations of androgens and prostate cell proliferation in our in vitro system of HNTEP culture cells could be seen as similar to the endocrine events occurring in male senescence and prostate growth. Thus, changes in the expression of the $p 21$ and $p 53$ genes might be part of the mechanisms by which low androgen concentrations are related to BPH. In this context, studies on suppressor genes continue to be performed, in order to find molecular markers for states of uncontrolled growth in target tissues for androgen action $(31,43,52-54)$. In conclusion, the present data showed that HNTEP cell proliferation could 
be induced by low androgen concentrations, and was related to lower $p 53$ and $p 21$ gene expression at these concentrations. Further studies are required to assess the intracellular signaling pathway regulated by $p 53$ and $p 21$ under the influence of androgen stimulation in human prostate epithelial cells and its implications for the pathophysiology of benign and neoplastic transformation of the human adult prostate.

\section{Acknowledgements}

The authors thank the Graduate Research Group (GPPG) at Clinical Hospital de Clínicas de Porto Alegre for the editorial support provided, and the Urology Services at Hospital de Clinicas de Porto Alegre, Hospital São Lucas/PUCRS and Hospital Ernesto Dorneles for the support in obtaining prostatic tissue. This study was supported in part by Fundação de Amparo à Pesquisa do Estado do Rio Grande do Sul (FAPERGS) and Conselho Nacional de Desenvolvimento Científico e Tecnológico (CNPq).

\section{References}

1. Sonnenschein C, Olea N, Pasanen ME and Soto AM: Negative controls of cell proliferation: human prostate cancer cells and androgens. Cancer Res 49: 3474-3781, 1989.

2. Long BJ, Grigoryev DN, Nnane IP, Liu Y, Ling YZ and Brodie AM: Antiandrogenic effects of novel androgen synthesis inhibitors on hormone-dependent prostate cancer. Cancer Res 60 : 6630-6640, 2000.

3. Haynes JM, Frydenberg M and Majewski H: Testosteroneand phorbol ester-stimulated proliferation in human cultured prostatic stromal cells. Cell Signal 13: 703-709, 2001.

4. Culig Z, Hobisch A, Bartsch G and Klocker H: Androgen receptor - an update of mechanisms of action in prostate cancer. Urol Res 28: 211-219, 2000.

5. Li TH, Zhao H, Peng Y, Beliakoff J, Brooks JD and Sun Z: A promoting role of androgen receptor in androgen-sensitive and -insensitive prostate cancer cells. Nucleic Acids Res 35: 2767-2776, 2007.

6. Yuan X, Li T, Wang H,Zhang T, Barua M, Borgesi RA, Bubley GJ, Lu ML and Balk SP: Androgen receptor remains critical for cell-cycle progression in androgen-independent CWR 22 prostate cancer cells. Am J Pathol 169: 682-696, 2006.

7. Blanchere M, Berthaut I, Portois MC, Mestayer C and Mowszowicz I: Hormonal regulation of the androgen receptor expression in human prostatic cells in culture. J Steroid Biochem Mol Biol 66: 319-326, 1998.

8. Avances C, Georget V, Terouanne B, Orio F, Cussenot O, Mottet N, Costa P and Sultan C: Human prostatic cell line PNT1A, a useful tool for studying androgen receptor transcriptional activity and its differential subnuclear localization in the presence of androgens and antiandrogens. Mol Cell Endocrinol 184: 13-24, 2001.

9. Planz B, Wang Q, Kirley SD, Marberger M and McDougal WS: Regulation of keratinocyte growth factor receptor and androgen receptor in epithelial cells of the human prostate. J Urol 166 : 678-683, 2001.

10. Nakano K, Fukabori Y, Itoh N, Lu W, Kan M, McKeehan WL and Yamanaka H: Androgen-stimulated human prostate epithelial growth mediated by stromal-derived fibroblast growth factor-10. Endocr J 46: 405-413, 1999.

11. Arnold JT, Liu X,Allen JD, Le H, McFann KK and Blackman MR: Androgen receptor or estrogen receptor-beta blockade alters DHEA-, DHT-, and E(2)-induced proliferation and PSA production in human prostate cancer cells. Prostate 67: 1152-1162, 2007.

12. Berthon P, Waller AS, Villette JM, Loridon L, Cussenot O and Maitland NJ: Androgens are not a direct requirement for the proliferation of human prostatic epithelium in vitro. Int J Cancer 73: 910-916, 1997.

13. Heisler LE, Evangelou A, Lew AM, Trachtenberg J, Elsholtz HP and Brown TJ: Androgen-dependent cell cycle arrest and apoptotic death in $\mathrm{PC}-3$ prostatic cell cultures expressing a full-length human androgen receptor. Mol Cell Endocrinol 126: 59-73, 1997.
14. Krill D, Stoner J, Konety BR, Becich MJ and Getzenberg RH: Differential effects of vitamin D on normal human prostate epithelial and stromal cells in primary culture. Urology 54: 171-177, 1999.

15. Joly-Pharaboz MO, Soave MC, Nicolas B, Mebarki F, Renaud M, Foury O, Morel Y and Andre JG: Androgens inhibit the proliferation of a variant of the human prostate cancer cell line LNCaP. J Steroid Biochem Mol Biol 55: 67-76, 1995.

16. Joly-Pharaboz MO, Ruffion A, Roch A, Michel-Calemard L, Andre J, Chantepie J, Nicolas B and Panaye G: Inhibition of growth and induction of apoptosis by androgens of a variant of LNCaP cell line. J Steroid Biochem Mol Biol 73: 237-249, 2000.

17. Shao C, Wang Y, Yue HH, Zhang YT, Shi CH, Liu F, Bao TY, Yang ZY, Yuan JL and Shao GX: Biphasic effect of androgens on prostate cancer cells and its correlation with androgen receptor coactivator dopa decarboxylase. J Androl 28: 804-812, 2007.

18. Geck P, Szelei J, Jimenez J, Lin TM, Sonnenschein C and Soto A: Expression of novel genes linked to the androgen-induced, proliferative shutoff in prostate cancer cells. J Steroid Biochem Mol Biol 63: 211-218, 1997.

19. Silva IS, Morsch DM, Urnauer L and Spritzer PM: Androgeninduced cell growth and c-myc expression in human non-transformed epithelial prostatic cells in primary culture. Endocr Res 27: 153-169, 2001.

20. Brum IS, Morsch DM, Pozzobon A, Boeri VA, Geib G and Spritzer PM: Androgen-dependent expression of c-jun and c-fos in human non-transformed epithelial prostatic cells: association with cell proliferation. Hormone Res 60: 209-214, 2003.

21. Buttyan R, Shabsigh A, Perlman H and Colombel M: Regulation of apoptosis in the prostate gland by androgenic steroids. Trends Endocrinol Metab 10: 47-54, 1999.

22. Solomon MJ and Kaldis P: Regulation of CDKs by phosphorylation. Results Probl Cell Differ 22: 79-109, 1998.

23. Waga S, Hannon GJ, Beach D and Stillman B: The p21 inhibitor of cyclin-dependent kinases controls DNA replication by interaction with PCNA. Nature 369: 574-578, 1994.

24. Sherr CJ and Roberts JM: CDK inhibitors: positive and negative regulators of G1-phase progression. Genes Dev 13: 1501-1512, 1999.

25. Robson CN, Gnanapragasam V, Byrne RL, Collins AT and Neal DE: Transforming growth factor-betal up-regulates p15, p21 and p27 and blocks cell cycling in G1 in human prostate epithelium. J Endocrinol 160: 257-266, 1999.

26. Lu S, Tsai SY and Tsai MJ: Molecular mechanisms of androgenindependent growth of human prostate cancer LNCaP-AI cells. Endocrinology 140: 5054-5059, 1999.

27. Ling MT, Chan KW and Choo CK: Androgen induces differentiation of a human papillomavirus 16 E6/E7 immortalized prostate epithelial cell line. J Endocrinol 170: 287-296, 2001.

28. Macleod KF, Sherry N, Hannon G, Beach D, Tokino T, Kinzler K, Vogelstein B and Jacks T: p53-dependent and independent expression of p21 during cell growth, differentiation, and DNA damage. Genes Dev 9: 935-944, 1995.

29. Downing S, Jackson P and Russell P: Mutations within the tumor suppressor gene p53 are not confined to a late event in prostate cancer progression: a review of the evidence. Urol Oncol 6: 103-110, 2001

30. Rokhlin OW, Taghiyev AF, Guseva NV, Glover RA, Chumakov PM, Kravchenko JE and Cohen MB: Androgen regulates apoptosis induced by TNFR family ligands via multiple signaling pathways in LNCaP. Oncogene 24: 6773-6784, 2005.

31. Wang LG, Ossowski L and Ferrari AC: Overexpressed androgen receptor linked to p21WAF1 silencing may be responsible for androgen independence and resistance to apoptosis of a prostate cancer cell line. Cancer Res 61: 7544-7551, 2001.

32. Spritzer PM, Silva IS, Oliveira IO, Morsch DM and Coral G: Culture of adult human prostatic epithelial cells: A simplified method for obtaining primary cultures. Med Sci Res 23: 379-381, 1995.

33. Mosmann T: Rapid colorimetric assay for cellular growth and survival: application to proliferation and cytotoxicity assays. J Immunol Methods 65: 55-63, 1983.

34. Taplin ME, Bubley GJ, Shuster TD, Frantz ME, Spooner AE, Ogata GK, Keer HN and Balk SP: Mutation of the androgenreceptor gene in metastatic androgen-independent prostate cancer. N Engl J Med 332: 1393-1398, 1995.

35. Bradford M: A rapid and sensitive method for quantitation of microgram quanties of protein utilizing the principle of proteindye binding. Anal Biochem 72: 248-255, 1976. 
36. Olea N, Sakabe K, Soto AM and Sonnenschein C: The proliferative effect of 'anti-androgens' on the androgen-sensitive human prostate tumor cell line LNCaP. Endocrinology 126: 1457-1463, 1990.

37. He B, Chen J, Basrawala Z, Xin H and Choubey D: The FXXLF motif mediates androgen receptor-specific interactions with coregulators. J Biol Chem 277: 10226-10235, 2002.

38. Chan TO, Rittenhouse SE and Tsichlis PN: AKT/PKB and other D3 phosphoinositide-regulated kinases: kinase activation by phosphoinositide-dependent phosphorylation. Annu Rev Biochem 68: 965-1014, 1999.

39. Rokhlin OW, Gudkov AV, Kwek S, Glover RA, Gewies AS and Cohen MB: p53 is involved in tumor necrosis factor-alphainduced apoptosis in the human prostatic carcinoma cell line LNCaP. Oncogene 19: 1959-1968, 2000.

40. Bruckheimer EM, Spurgers K, Weigel NL, Logothetis C and McDonnell TJ: Regulation of Bcl-2 expression by dihydrotestosterone in hormone sensitive LNCaP-FGC prostate cancer cells. J Urol 169: 1553-1557, 2003.

41. Nantermet PV, Xu J, Yu Y, Hodor P, Holder D, Adamski S, Gentile MA, Kimmel DB, Harada S, Gerhold D, et al: Identification of genetic pathways activated by the androgen receptor during the induction of proliferation in the ventral prostate gland. J Biol Chem 279: 1310-1322, 2004

42. Khan OY, Fu G, Ismail A, Srinivasan S, Cao X, Tu Y, Lu S and Nawaz Z: Multifunction steroid receptor coactivator, E6-associated protein, is involved in development of the prostate gland. Mol Endocrinol 20: 544-559, 2006.

43. Zhou JR, Yu L, Zerbini LF, Libermann TA and Blackburn GL: Progression to androgen-independent $\mathrm{LNCaP}$ human prostate tumors: cellular and molecular alterations. Int J Cancer 110 : 800-806, 2004.

44. Schwarze SR, Shi Y, Fu VX, Watson PA and Jarrard DF: Role of cyclin-dependent kinase inhibitors in the growth arrest at senescence in human prostate epithelial and uroepithelial cells. Oncogene 20: 8184-8192, 2001.
45. Li R, Waga S, Hannon GJ, Beach D and Stillman B: Differential effects by the p21 CDK inhibitor on PCNA-dependent DNA replication and repair. Nature 371: 534-537, 1994.

46. Lu S, Jenster G and Epner DE: Androgen induction of cyclindependent kinase inhibitor $\mathrm{p} 21$ gene: role of androgen receptor and transcription factor Sp1 complex. Mol Endocrinol 14: 753-760, 2000.

47. Yeh S, Hu YC, Rahman M, Lin HK, Hsu CL, Ting HJ, Kang HY and Chang $C$ : Increase of androgen-induced cell death and androgen receptor transactivation by BRCA1 in prostate cancer cells. Proc Natl Acad Sci USA 97: 11256-11261, 2000.

48. Lu S, Liu M, Epner DE, Tsai SY and Tsai MJ: Androgen regulation of the cyclin-dependent kinase inhibitor p21 gene through an androgen response element in the proximal promoter. Mol Endocrinol 13: 376-384, 1999.

49. Alimirah F, Chen J, Basrawala Z, Xin H and Choubey D: DU-145 and PC-3 human prostate cancer cell lines express androgen receptor: implications for the androgen receptor functions and regulation. FEBS Lett 580: 2294-2300, 2006.

50. Carey JP, Asirvatham AJ, Galm O, Ghogomu TA and Chaudhary J: Inhibitor of differentiation 4 (Id4) is a potential tumor suppressor in prostate cancer. BMC Cancer 9: 173, 2009.

51. McConnell JD: Prostatic growth: new insights into hormonal regulation. Br J Urol 76: 5-10, 1995.

52. Gotoh A, Shirakawa T, Wada Y, Fujisawa M, Okada H, Kamidono S and Hamada K: The growth inhibitory effect of p21 adenovirus on androgen-dependent and -independent human prostate cancer cells. BJU Int 92: 314-318, 2003.

53. Miyake H, Tolcher A and Gleave ME: Antisense Bcl-2 oligodeoxynucleotides inhibit progression to androgen-independence after castration in the Shionogi tumor model. Cancer Res 59: 4030-4034, 1999.

54. Concato J, Jain D, Uchio E, Risch H, Li WW and Wells CK: Molecular markers and death from prostate cancer. Ann Intern Med 150: 595-603, 2009. 